\title{
Variational Method for Estimating the Dipole Moment in the Second Excited State of Fluorescein Molecule from its Electronic UV Absorption Spectra
}

\author{
ALINA COSTINA LUCA ${ }^{1}$, ANA CEZARINA MOROSANU2, IRINA MACOVEI ${ }^{3}$, DAN GHEORGHE DIMITRIU², \\ DANA ORTANSA DOROHOI², IOAN SORIN STRATULAT ${ }^{4}$ \\ ${ }^{1}$ Grigore T. Popa University of Medicine and Pharmacy, 16 Universitatii Str., 700115, Iasi, Romania \\ ${ }^{2}$ Alexandru Ioan Cuza University, Faculty of Physics, 11 Carol I Blvd., 700506, Iasi, Romania \\ ${ }^{3}$ Grigore T. Popa University of Medicine and Pharmacy, Faculty of Pharmacy, 16 Universitatii Str., 700115, Iasi, Romania \\ ${ }^{4}$ Gr.igore T. Popa University of Medicine and Pharmacy, Department of Implantology/Rehabilitation Medicine, Balneology and \\ Physical Therapy, 16 Universitatii Str., 700115, Iasi, Romania
}

\begin{abstract}
Electro-optical parameters of fluorescein molecule in the second excited electronic state and information on the interactions with solvents were obtained from a solvatochromic study. Parameters of the solvents such as the refractive index, electrical permittivity and Kamlet-Taft parameters (hydrogen bond acidity and basicity) were related with the experimentally recorded shifts of UV absorption spectral band of fluorescein dissolved in several solvents. Through a variational method, the electric dipole moment and polarizability in excited state of fluorescein molecule were estimated. The calculus requires some parameters of the fluorescein molecule in the ground electronic state, which were determined through a quantum-mechanical study.
\end{abstract}

Keywords: fluorescein; solvatochromism; dipole moment in the second excited state; UV spectra; quantummechanical characterization

Fluorescein is a fluorophore pigment first synthesized by Adolf von Baeyer in 1871 [1] by heating phthalic anhydride and resorcinol over a zinc catalyst. Depending on the $\mathrm{pH}$ of the solution, fluorescein exists in seven prototropic forms with different photo-physical properties: three neutral forms and four charged forms [2].

The large rigid $\pi$-conjugated structure of fluorescein determines an intense absorption and emission in the visible wavelengths, high photo-stability and high fluorescence quantum yield [3]. These properties make the fluorescein a very good candidate for a wide range of applications. However, it is most widely used as a fluorescence label due to its low cost, high absorptivity and good quantum yield when conjugated to the biomolecules, being used as standard for the calculation of quantum efficiency by relative fluorescence quantum yields methods [4].

Fluorescein is a well-known substance in medicine, being intensively used into a lot of applications. Thus, in ophthalmology, fluorescein is the most used stain, with important applications in both clinical practice and research. Fluorescein is used in investigation of lacrimal characteristics, by observing the normal and pathological pleats of the conjunctiva, and obtaining knowledge about aqueoserous tear secretion, its complex flow along the lacrimal pool and its clearance [5]. In addition, fluorescein is used in the measurement of intraocular pressure with Goldmann applanation tonometry [6], as well as to observe various ocular surface pathologies. Recently, a new methodology for tear-film dynamics assessment was introduced in ophthalmology and called fluorescein profilometry [7]. Ultra-widefield fluorescein angiography is a technique that enables a visualization of up to 200 degrees of the eye's retina within a single scan [8].

Beside ophthalmology, fluorescein is also widely used in other branches of medicine. Thus, fluorescein fluorescence technology is a valuable tool in the surgical management of neoplastic and vascular lesions [9]. By using a microscope-integrated fluorescence module, this technique allows performing intraoperative angiography to guide microsurgical management of aneurysms and arteriovenous malformations, as well as the maximization of tumor resection [10]. A comprehensive review on the fluorescein-guided surgery of malignant gliomas can be found in [11]. Dermofluorometry is a technique used for skin microcirculation evaluating, as for example the assessment of diabetic microvascular disease, consisting of measurements of skin fluorescence after an injection of sodium fluorescein [12]. Photobleaching of fluorescein is used as a probe to detect the response of individual cells to oxidative stress and the intracellular reactive oxygen species [13]. As photodynamic sensitizer, fluorescein is of great value in fluorescence immunoassays. Thus, fluorescein derivatives silver nanohybrids have a very good antimicrobial activity against different bacterial strains and fungi [14]. Encapsulated in protective hollow silica nanospheres, fluorescein molecules were used as labels for a biosensor for the rapid detection of Escherichia coli 0157:H7 [15]. Biocompatible silica-gelatin hybrid aerogels covalently labeled with fluorescein were recently introduced as drug delivery devices [16]. For fluorescent monitoring of drug delivery in vivo, fluorescein based chemosensors connected to anticancer drugs were used [17]. Fluorescein is used for synthetization of fluorescein labelled cationic carbosilane dendrimers and dendrons, for biomedical applications (carriers in gene therapy) [18].

Fluorescein is often used in the construction of different kind of sensors for relative humidity, ultraviolet light and temperature monitoring, sensitive blood detection, thiols biological imaging, ammonia and picric acid $(2,4,6-$ trinitrophenol) detection, rapid and selective detection of gold(III), $\mathrm{Zn}^{2+}, \mathrm{Al}^{3+}, \mathrm{Cu}^{2+}, \mathrm{S}^{2-}$ and $\mathrm{Fe}^{3+}$ ions, highly selective and sensitive detection of sulfite in aqueous solution and cysteine over other amino acids $[19,20]$. 
In optoelectronics, fluorescein dye is well known as a good laser medium in the visible region of the spectrum, being notable for its moderate fluorescence quantum yield and photostability [21]. Nanocrystalline thin films of fluorescein dye were proposed as good candidates for the fabrication of optoelectronic/nonlinear optical devices [22]. Solar cells have been designed based on nanostructured titanium dioxide sensitized with fluorescein sodium salt [23].

Other application of fluorescein dyes are in ground water tracing studies [24], seed security [25], ratiometric fluorescence imaging of nuclear pH in living cells [26] and as an exceptionally simple molecular arithmetic system [27].

Solvatochromism describes the pronounced change in the position and sometimes intensity of a molecular UVVis absorption band of solute induced by changes in solvent polarity. Solvatochromic properties of fluorescein have been studied in both aqueous and nonaqueous solvents [3, 2833]. Based of Lippert's, Bakshiev's and Chamma-Viallet's equations, Acemioolu et al. estimated the excited-state dipole moment in the first excited state of fluorescein in different solvents [31], using information from both absorption and fluorescence spectra. Recently, the dipole moment in the first excited state of fluorescein, as well as the angle between the dipole moments characterizing the electronic states participating to the absorption photons from the visible range were determined [34].

The excited state dipole moment of the molecules can be also estimated based on Abe model [35] but a very great number of parameters even for the solvent and for solute molecule must be known. The electric dipole moments in the electronic states participating to the absorption and emission process were estimated for anthracene using Abe model [36-38].

The aim of this study was to apply the variation method in order to estimate the molecular dipole moment in the second excited electronic state of fluorescein.

\section{Experimental part}

Fluorescein was purchased from Sigma-Aldrich Chemical Company and it was used without purification. The skeletal formula of fluorescein molecule with labeled atoms is displayed in Fig. 1.

Density Functional method of Spartan'14 program [39, 40] was used to compute some theoretical properties of fluorescein. Spartan is a molecular modeling program using

\begin{tabular}{|c|c|c|c|c|c|}
\hline No. & Solvent & $f(\varepsilon)$ & $f(n)$ & $\beta$ & $\alpha$ \\
\hline 1 & 1,4-Dioxane & 0.2941 & 0.2541 & 0.37 & 0.00 \\
\hline 2 & Diethyl ether & 0.5261 & 0.2163 & 0.47 & 0.00 \\
\hline 3 & Chloroform & 0.5595 & 0.2667 & 0.10 & 0.20 \\
\hline 4 & Ethyl acetate & 0.6259 & 0.2273 & 0.45 & 0.00 \\
\hline 5 & Dichloromethane & 0.7255 & 0.2552 & 0.10 & 0.13 \\
\hline 6 & 1,2-Dichloroethane & 0.7573 & 0.2661 & 0.10 & 0.00 \\
\hline 7 & 1-Hexanol & 0.8039 & 0.2520 & 0.84 & 0.80 \\
\hline 8 & 1-Pentanol & 0.8113 & 0.2467 & 0.86 & 0.84 \\
\hline 9 & 1-Butanol & 0.8462 & 0.2419 & 0.84 & 0.84 \\
\hline 10 & 2-Propanol & 0.8631 & 0.2300 & 0.84 & 0.76 \\
\hline 11 & Ethanol & 0.8870 & 0.2212 & 0.75 & 0.86 \\
\hline 12 & Methanol & 0.9135 & 0.2029 & 0.66 & 0.98 \\
\hline 13 & N,N-Dimethylformamide & 0.9225 & 0.2588 & 0.69 & 0.00 \\
\hline 14 & N,N-Dimethylacetamide & 0.9246 & 0.2625 & 0.76 & 0.00 \\
\hline
\end{tabular}

Table 1 SOLVENT POLARITY FUNCTION $f(\varepsilon)$, SOLVENT POLARIZABILITY FUNCTION $f(n)$ AND KAMLET-TAFT SOLVENT PARAMETERS ( $\alpha$ - HYDROGEN BOND DONOR, $\beta$ - HYDROGEN BOND ACCEPTOR) molecular mechanics and quantum chemical calculations. Spartan offers a variety of graphical tools for interpreting the results of calculations: structure models, ionization potentials and electrostatic potentials that can

The solvents achieved from Merck were of high spectral purity. The solvent polarity $f(n)=\frac{n^{2}-1}{n^{2}+1}$ and polarizability $f(\varepsilon)=\frac{\varepsilon-1}{\varepsilon+1}$ functions on refractive index and electric permittivity [41, 42], respectively, are listed in Table 1, which also contains the Kamlet-Taftsolvent parameters hydrogen bond donor $(\alpha)$ and hydrogen bond acceptor ( $\beta$ ) [43-46].

Ultraviolet electronic absorption spectra of fluorescein were recorded in 14 solvents at room temperature, with QE65000 UV-Vis Ocean-Optics spectrometer.

performed by Origin 9 program.

\section{Results and discussions}

The chemical structure of fluorescein was optimized by Spartan'14 program. The lengths of interatomic chemical bonds (calculated with Spartan'14) of fluorescein molecule are listed in Table 2. As itcan be seen, the longest chemical bonds are C7-C14 (1.490 $\AA)$, C19-C20 (1.489 $\AA)$ and C11-

The measure of some dihedral angles are listed in Table 3. From the data presented here, it results that fluorescein $\mathrm{H} 5(0.969 \AA)$ ) and $05-\mathrm{H} 1(0.975 \AA)$. 
Table 2

LENGTHS OF INTERATOMIC CHEMICAL BONDS OF FLUORESCEIN MOLECULE

\begin{tabular}{|c|c|c|c|c|c|c|c|}
\hline $\begin{array}{c}\text { Chemical } \\
\text { bond }\end{array}$ & $\begin{array}{l}\text { Bond length } \\
\text { (A) }\end{array}$ & $\begin{array}{c}\text { Chemical } \\
\text { bond }\end{array}$ & $\begin{array}{l}\text { Bond length } \\
\text { (A) }\end{array}$ & $\begin{array}{c}\text { Chemical } \\
\text { bond }\end{array}$ & $\begin{array}{l}\text { Bond length } \\
\text { (A) }\end{array}$ & $\begin{array}{c}\text { Chemical } \\
\text { bond }\end{array}$ & $\begin{array}{l}\text { Bond length } \\
\text { (A) }\end{array}$ \\
\hline $\mathrm{Cl}-\mathrm{C} 3$ & 1.390 & $\mathrm{C} 2-\mathrm{H}_{3}$ & 1.084 & C13-C8 & 1.441 & C16-C18 & 1.390 \\
\hline $\mathrm{C} 3=\mathrm{C} 6$ & 1.403 & C4-O1 & 1.351 & $\mathrm{C} 10-\mathrm{H} 6$ & 1.083 & $\mathrm{C} 18=\mathrm{C} 14$ & 1.396 \\
\hline $\mathrm{C} 6-\mathrm{C} 2$ & 1.378 & $\mathrm{C5}-\mathrm{C} 7$ & 1.438 & $\mathrm{C} 11=03$ & 1.233 & C18-H12 & 1.085 \\
\hline $\mathrm{C}_{2}=\mathrm{C}_{5}$ & 1.407 & O1-C9 & 1.369 & $\mathrm{C} 12-\mathrm{H} 7$ & 1.085 & C16-H10 & 1.085 \\
\hline $\mathrm{C5}-\mathrm{C4}$ & 1.406 & $\mathrm{C} 7=\mathrm{C} 8$ & 1.374 & C13-H8 & 1.085 & C17-H11 & 1.085 \\
\hline $\mathrm{C} 4=\mathrm{Cl}$ & 1.389 & C8-C9 & 1.446 & C7-C14 & 1.489 & $\mathrm{C} 15-\mathrm{H} 9$ & 1.083 \\
\hline $\mathrm{C} 1-\mathrm{H} 2$ & 1.085 & $\mathrm{Cg}=\mathrm{C} 10$ & 1.354 & C14-C19 & 1.408 & C19-C20 & 1.484 \\
\hline $\mathrm{C} 3-\mathrm{O} 2$ & 1.353 & C10-C11 & 1.453 & $\mathrm{C} 19=\mathrm{C} 15$ & 1.399 & $\mathrm{C} 20-04$ & 1.352 \\
\hline O2-H5 & 0.969 & C11-C12 & 1.471 & C15-C17 & 1.387 & $\mathrm{C} 20=05$ & 1.211 \\
\hline $\mathrm{C} 6-\mathrm{H} 4$ & 1.083 & $\mathrm{C} 12=\mathrm{C} 13$ & 1.349 & $\mathrm{C} 17=\mathrm{C} 16$ & 1.391 & O4-H13 & 0.974 \\
\hline
\end{tabular}

\begin{tabular}{|c|c|c|c|}
\hline Dihedral angle & Measure & Dihedral angle & Measure \\
\hline$(\mathrm{C} 6, \mathrm{C} 2, \mathrm{C} 5, \mathrm{C} 7)$ & $-0.46^{\circ}$ & $(\mathrm{C} 5, \mathrm{C} 7, \mathrm{C} 14, \mathrm{C} 19)$ & $-85.29^{\circ}$ \\
\hline$(\mathrm{C} 5, \mathrm{C} 7, \mathrm{C} 8, \mathrm{C} 13)$ & $-179.51^{\circ}$ & $(\mathrm{C} 14, \mathrm{C} 19, \mathrm{C} 20,05)$ & $-0.69^{\circ}$ \\
\hline (C10,C11,C12,03) & $179.98^{\circ}$ & $(\mathrm{C} 19, \mathrm{C} 20,04, \mathrm{H} 13)$ & $179.75^{\circ}$ \\
\hline$(\mathrm{C} 1, \mathrm{C} 3, \mathrm{O} 2, \mathrm{H} 5)$ & $-0.75^{\circ}$ & $(\mathrm{C} 1, \mathrm{C} 4,01, \mathrm{C9})$ & $-179.46^{\circ}$ \\
\hline
\end{tabular}

Table 4

MOLECULAR PROPERTIES OF FLUORESCEIN, COMPUTED BY SPARTAN'14 PROGRAM

\begin{tabular}{|l|l|l|l|}
\hline Molecular parameter & Value & $\begin{array}{l}\text { Quantitative } \\
\text { Structure-Activity } \\
\text { Relationship (QSAR) }\end{array}$ & Value \\
\hline$E_{\text {HoMO }}(\mathrm{eV})$ & -5.27 & Area $\left(\mathrm{A}^{2}\right)$ & 321.44 \\
\hline$E_{\text {LuMo }}(\mathrm{eV})$ & -2.29 & Volume $\left(\mathrm{A}^{3}\right)$ & 316.32 \\
\hline Dipole Moment (D) & 7.94 & PSA $\left(\mathrm{A}^{2}\right)$ & 72.305 \\
\hline Tautomers & 3 & Log P & -0.91 \\
\hline Conformers & 8 & Polarizability $\left(\mathrm{A}^{3}\right)$ & 66.33 \\
\hline & & HBD Count & 2 \\
\hline & & HBA Count & 4 \\
\hline
\end{tabular}

molecule consists of a plane determined by three cycles connected through a simple covalent bond C7-C14 (Fig. 1) by a benzene cycle substituted at $\mathrm{C} 19$ by $-\mathrm{COOH}$ atomic group. The benzene cycle is almost perpendicular to the plane determined by the three cycles (the dihedral angle $\mathrm{C} 5, \mathrm{C} 7, \mathrm{C} 14, \mathrm{C} 19$ is $\left.-85.29^{\circ}\right)$.

The atomic and molecular properties of fluorescein were computed using EDF2/6-31G* density functional and QSAR models, several of them being listed in Table 4 .

The charge distribution in a molecule determines its physical and chemical properties. Chemical reactions are associated with charged sites. The most highly-charged site in a molecule is often the most reactive one. Fig. 2 shows the atomic electrostatic charges of fluorescein (expressed in percent of elementary charge), computed by density functional method of Spartan'14.

HOMO (highest occupied molecular orbital) and LUMO (lowest unoccupied molecular orbital) give, by their modulus, the ionization potential and the electron affinity of the fluorescein [47]. They are the mostimportantorbitals with respect to reactivity [47]. The frontier orbitals of fluorescein molecule are shown in Fig. $3 a$ (HOMO surface) and Fig. 3b (LUMO surface), respectively.
Table 3

THE MEASURE OF SOME DIHEDRAL ANGLES OF FLUORESCEIN MOLECULE

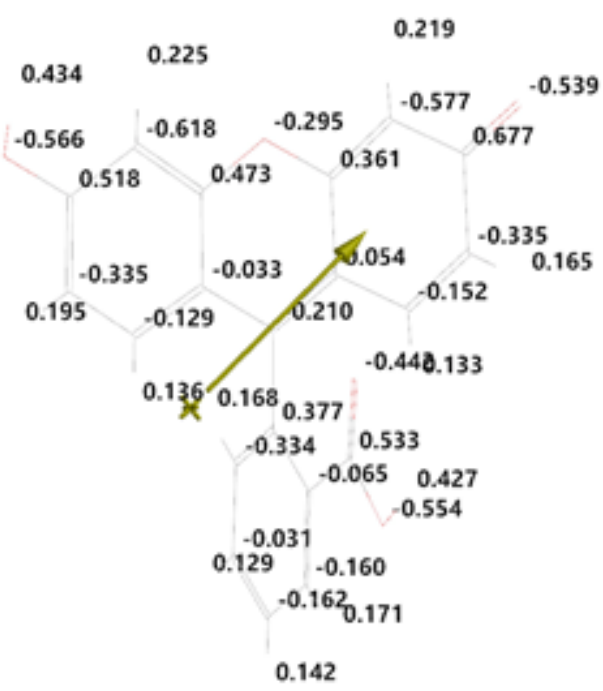

Fig. 2. Electrostatic charges of fluorescein molecule, computed by Spartan program (The arrow indicates the orientation of the dipole moment of the molecule)

The partition coefficient [48] is defined as a particular ratio of the concentrations of a solute between the two solvents. When water is one of the solvents and the other one is a non-polar solvent, then $\log P$ value is a measure of hydrophilicity or hydrophobicity. Fluorescein molecule has a hydrophilic character because $\log P=-0.91<0$.

The polar surface area (PSA) of a molecule is defined as the surface sum over all polar atoms, primarily oxygen and nitrogen, including also their attached hydrogen atoms. In medical chemistry, PSA is used for the optimization of a drug's ability to permeate cells. Molecules of fluorescein having PSA $=72.3 \AA^{2}$ can traverse both the cell membranes (PSA must be less than $140 \AA^{2}$ ) and the blood-brain barrier (PSA must be less than $90 \AA^{2}$ ) [49].

Fig. 4 shows the ultraviolet electronic absorption bands of fluorescein in several solvents. The wavenumbers from the maxima of absorption bands were determined for 14 solvents.

The experimental values of the wavenumbers in the maximum of the UV band of fluorescein in different solvents are listed in Tables 5. 


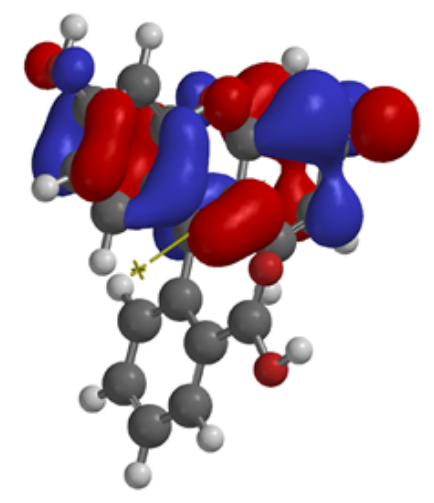

(a)

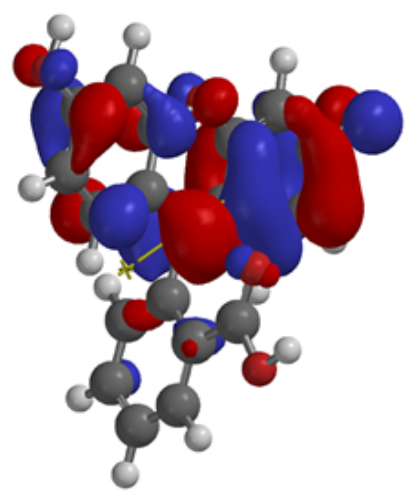

(b)
Fig. 3. HOMO (a), LUMO (b) surfaces of fluorescein molecule

Table 5

EXPERIMENTAL AND COMPUTED (USING FORMULA (2)) WAVENUMBERS IN THE MAXIMUM OF UV ABSORPTION BAND OF FLUORESCEIN

\begin{tabular}{|l|c|c|l|c|c|}
\hline Solvent & $\begin{array}{c}\bar{v}_{\text {exp }} \\
\left(\mathrm{cm}^{-1}\right)\end{array}$ & $\begin{array}{c}\bar{v}_{\text {caic }} \\
\left(\mathrm{cm}^{-1}\right)\end{array}$ & \multicolumn{1}{|c|}{ Solvent } & $\begin{array}{c}\bar{v}_{\text {exp }} \\
\left(\mathrm{cm}^{-1}\right)\end{array}$ & $\begin{array}{c}\bar{v}_{\text {caic }} \\
\left(\mathrm{cm}^{-1}\right)\end{array}$ \\
\hline 1,4-Dioxane & 36476.38 & 36425.90 & 1-Pentanol & 36268.68 & 36237.29 \\
\hline Diethyl ether & 36476.38 & 36511.64 & 1-Butanol & 36268.68 & 36252.36 \\
\hline Chloroform & 36371.57 & 36411.50 & 2-Propanol & 36320.05 & 36294.36 \\
\hline Ethyl acetate & 36476.38 & 36478.76 & Ethanol & 36320.05 & 36321.62 \\
\hline DCM & 36476.38 & 36442.62 & Methanol & 36371.57 & 36373.17 \\
\hline 1,2-DCE & 36423.24 & 36411.50 & N,N-DMF & 36371.57 & 36329.89 \\
\hline 1-Hexanol & 36165.06 & 36231.36 & N,N-DMA & 36268.68 & 36306.85 \\
\hline
\end{tabular}

The total shift of the electronic bands can be described by the following relation [50-53]:

$$
\bar{\nu}_{\text {calc }}=\bar{\nu}_{0}+C_{1} f(\varepsilon)+C_{2} f(n)+C_{3} \beta+C_{4} \alpha,
$$

where $\bar{\nabla}_{0}\left(\mathrm{~cm}^{-1}\right)$ has the significance of the wavenumber in the maximum of absorption electronic band for gaseous phase of the spectrally active substance and $C_{1}-C_{4}$ are the regression coefficients obtained by multilinear regression analysis. The terms $\mathrm{C}_{1} \mathrm{f}(\varepsilon)$ and $\mathrm{C}_{2}(\mathrm{n})$ give the contribution of the universal interâctions by orientation-induction and polarization-dispersion processes, respectively, while the terms $C_{3} \beta$ and $C_{4} \alpha$ give the contribution of the specific interactions to the total spectral shift.

When the solvent parameters and the experimental wavenumber of the absorption band are known, a multilinear regression applied to formula (1) allow estimating the regression coefficients from Table 6.
Using the values of these coefficients, the relation (1) can be written as:

$$
\bar{v}_{\text {cats }}\left(\mathrm{cm}^{-1}\right)=37232.1-57.5 f(\varepsilon)-2797.2 f(n)-181.2 \beta-121.6 \alpha,
$$

The computed (by using the relation (2)) wavenumbers in the maxima of UV band are listed in Table 5. The computed wavenumbers $\frac{v_{\text {calc }}}{\left(\mathrm{cm}^{-1}\right)}$ versus the experimental wavenumbers $\bar{v}$ calc $\left(\mathrm{cm}^{-1}\right)$ are plotted in Fig. 5. A good linear dependence between the experimental and calculated values of the wave numbers was obtained: the slope is 0.88 , the regression coefficient is $R=0.87$ and the standard deviation is SD $=33.19$.

The contribution of each type of interaction to the total spectral shift in different solvents, in $\mathrm{cm}^{-1}$ and in percentage $(\%)$, is listed in Table 7. The data show that the dispersionpolarization interactions have the greatest contribution to

Table 6

REGRESSION COEFFICIENTS OBTAINED BY MULTILINEAR REGRESSION ANALYSIS FOR ELECTRONIC ABSORPTION BAND OF FLUORESCEIN IN ULTRAVIOLET

\begin{tabular}{|c|c|c|c|c|c|c|c|c|c|c|c|}
\hline \multicolumn{2}{|c|}{ Intercept } & \multicolumn{2}{c|}{$C_{1}\left(\mathrm{~cm}^{-1}\right)$} & \multicolumn{2}{c|}{$C_{2}\left(\mathrm{~cm}^{-1}\right)$} & \multicolumn{2}{c|}{$C_{3}\left(\mathrm{~cm}^{-1}\right)$} & \multicolumn{2}{c|}{$C_{4}\left(\mathrm{~cm}^{-1}\right)$} & \multicolumn{2}{c|}{ Statistics } \\
\hline Value & Error & Value & Enror & Value & Error & Value & Error & Value & Error & $\begin{array}{c}\text { Adj. R- } \\
\text { Root- } \\
\end{array}$ \\
& & & & & & & & & & & \\
Square & $\begin{array}{c}\text { MSE } \\
\text { (SD) }\end{array}$ \\
\hline 37232.07 & 164.44 & -57.55 & 78.44 & -2797.18 & 651.01 & -181.22 & 55.38 & -121.64 & 39.04 & 0.826 & 40.86 \\
\hline
\end{tabular}




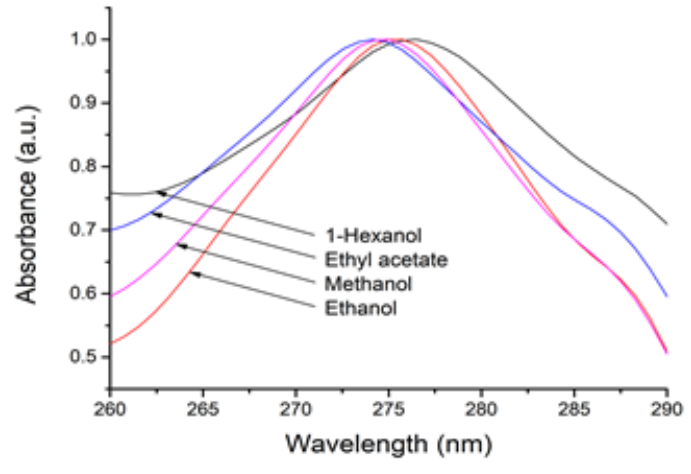

Fig. 4. Ultraviolet electronic absorption band of fluorescein in four solvents (1-hexanol, ethyl acetate, methanol and ethanol, respectively)

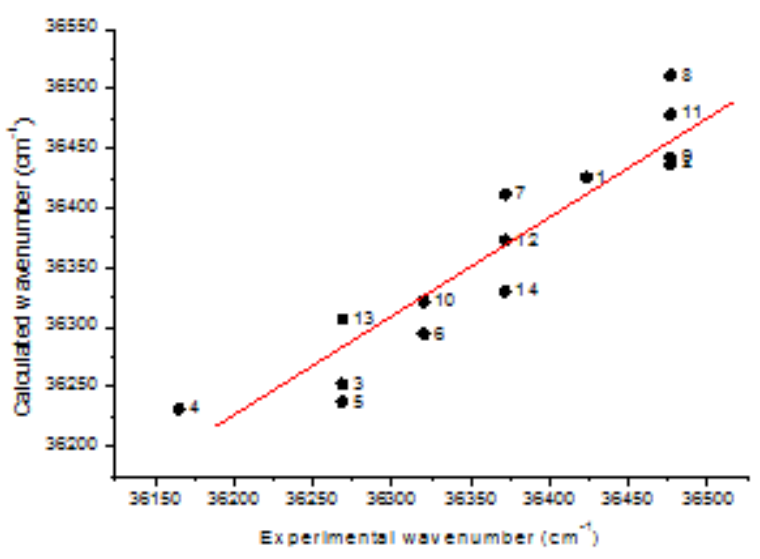

Fig. 5. $\bar{v}_{\text {calc }}$ (calculated using relation (2)) vs. $\overline{v_{\text {exp }}}$ for the UV electronic absorption band of fluorescein

\begin{tabular}{|c|c|c|c|c|c|c|c|c|}
\hline Solvent & $\begin{array}{l}C_{1}(\varepsilon) \\
\left(\mathrm{cm}^{-1}\right)\end{array}$ & $p_{1} \%$ & $\begin{array}{l}C_{2} f(n) \\
\left(\mathrm{cm}^{-1}\right)\end{array}$ & $p_{2} \%$ & $\begin{array}{c}C_{3 \beta} \beta \\
\left(\mathrm{cm}^{-1}\right)\end{array}$ & $p_{3} \%$ & $\begin{array}{c}C_{4} \alpha \\
\left(\mathrm{cm}^{-1}\right)\end{array}$ & $p_{4} \%$ \\
\hline 1,4-Dioxane & 16.9 & 2.1 & 710.8 & 89.4 & 67.1 & 8.4 & 0.0 & 0.0 \\
\hline Diethyl ether & 30.3 & 4.2 & 605.0 & 84.0 & 85.2 & 11.8 & 0.0 & 0.0 \\
\hline Chloroform & 32.2 & 3.9 & 745.9 & 90.9 & 18.1 & 2.2 & 24.3 & 3.0 \\
\hline Ethyl acetate & 36.0 & 4.8 & 635.7 & 84.4 & 81.5 & 10.8 & 0.0 & 0.0 \\
\hline DCM & 41.8 & 5.3 & 713.8 & 90.4 & 18.1 & 2.3 & 15.8 & 2.0 \\
\hline $1,2-\mathrm{DCE}$ & 43.6 & 5.4 & 744.5 & 92.3 & 18.1 & 2.2 & 0.0 & 0.0 \\
\hline 1-Hexanol & 46.3 & 4.6 & 704.9 & 70.4 & 152.2 & 15.2 & 97.3 & 9.7 \\
\hline 1-Pentanol & 46.7 & 4.7 & 690.1 & 69.4 & 155.8 & 15.7 & 102.2 & 10.3 \\
\hline 1-Butanol & 48.7 & 5.0 & 676.6 & 69.1 & 152.2 & 15.5 & 102.2 & 10.4 \\
\hline 2-Propanol & 49.7 & 5.3 & 643.4 & 68.6 & 152.2 & 16.2 & 92.4 & 9.9 \\
\hline Ethanol & 51.0 & 5.6 & 618.9 & 68.0 & 135.9 & 14.9 & 104.6 & 11.5 \\
\hline Methanol & 52.6 & 6.1 & 567.5 & 66.1 & 119.6 & 13.9 & 119.2 & 13.9 \\
\hline $\mathrm{N}, \mathrm{N}-\mathrm{DMF}$ & 53.1 & 5.9 & 724.0 & 80.3 & 125.0 & 13.9 & 0.0 & 0.0 \\
\hline $\mathrm{N}, \mathrm{N}-\mathrm{DMA}$ & 53.2 & 5.8 & 734.3 & 79.4 & 137.7 & 14.9 & 0.0 & 0.0 \\
\hline
\end{tabular}

Table 7

CONTRIBUTION OF EACH TYPE OF INTERACTION TO THE TOTAL SPECTRAL SHIFT IN ULTRAVIOLET DOMAIN the total spectral shift. The weight of dispersionpolarization interactions is between 66.1 and $92.3 \%$.

If only the electronic absorption spectra of a molecule in different solvents are available, a variational method could be applied to obtain information on both the electric dipole moment in the excited state of the studied molecule and the angle between the dipole moments in the electronic states participating in absorption process. Such a procedure, described below, was successfully applied for other molecules [52-56].

The regression coefficients $C_{1}$ and $C_{2}$ from relation (1) depend on the microscopic parameters of the solute molecule $[52,53]$ :

$$
C_{1}=\frac{2 \mu_{g}\left(\mu_{g}-\mu_{\varepsilon} \cos \varphi\right)}{h c a^{3}}+3 k T \frac{\alpha_{g}-\alpha_{\varepsilon}}{a^{3}},
$$

$$
C_{2}=\frac{\mu_{g}^{2}-\mu_{\varepsilon}^{2}}{h c a^{3}}-\frac{2 \mu_{g}\left(\mu_{g}-\mu_{\varepsilon} \cos \varphi\right)}{h c a^{3}}-3 k T \frac{\alpha_{g}-\alpha_{\varepsilon}}{a^{3}}+\frac{3}{2} \frac{\alpha_{g}-\alpha_{\varepsilon}}{a^{3}} \frac{I_{u} I_{v}}{I_{u}+I_{v}} .
$$

Using Eqs. (3) and (4), the dipole moment and the polarizability of the spectrally active molecule in excited state can be estimated. Thus, from Eqs. (3) and (4) the next relation can be obtained:

$$
C_{1}+C_{2}=\frac{\mu_{g}^{2}-\mu_{s}^{2}}{h c a^{3}}+\frac{3}{2} \frac{\alpha_{g}-\alpha_{e}}{a^{3}} \frac{I_{u} I_{v}}{I_{u}+I_{v}} .
$$

The molecular radius a can be calculated function of the values of volume and surface area in the ground state of the molecule (Table 1):

$$
a=\frac{3 \mathrm{~V}}{\mathrm{~A}} \text {. }
$$

For the fluorescein molecule, the radius can be approximated by $a=2.9522 \AA=2.9522 .10^{-8} \mathrm{~cm}$.

In Eqs. (3)-(5) the following notations were made: $\mu$ and $\mu$-the dipole moments of the spectrally active molecule in the ground and excited states, respectively, $\varphi$ -the angle between them, $a_{a}$ and $a_{\text {e }}$-the polarizabilities of the molecule in its ground and excited states, respectively, $c$-the speed of light in vacuum, a -the radius of molecule, $h$-the Planck's constant, $k$-the Boltzmann's constant, $T$ the absolute temperature, $I_{u}$-the ionization potential of the spectrally active molecule, $I$, the ionization potential of the solvent molecule. Chloroform $\left(I_{v}=8.4 \mathrm{eV}\right)$ was the solvent used to calculate the polarizability and the dipole moment of fluorescein molecule in the excited state.

The following data are used in the calculus: $\mu_{g}=7.94 \mathrm{D}$, $\alpha_{g}=66.33 \AA^{3}, \quad a=2.9522 \AA, \quad I_{u}=-E_{\text {HOMO }}=5.27 \mathrm{eV}$; $I_{v}=8.4 \mathrm{eV} ; C_{1}=-57.55 \mathrm{~cm}^{-1} ; C_{2}=-2797.18 \mathrm{~cm}^{-1}$ (Tables 1 and 6). One obtains the following equations: 


\begin{tabular}{|c|c|c|c|c|c|}
\hline $\begin{array}{c}\text { Angle } \varphi \\
\text { (degrees) }\end{array}$ & $\mu_{\mathrm{c}}(\mathrm{D})$ & $\alpha_{\mathrm{c}}\left(\AA^{3}\right)$ & $\begin{array}{c}\text { Angle } \varphi \\
\text { (degrees) }\end{array}$ & $\mu_{\mathrm{s}}(\mathrm{D})$ & $\alpha_{c}\left(\AA^{3}\right)$ \\
\hline 0 & 7.94 & 68.52 & 30 & 9.20 & 65.28 \\
\hline 10 & 8.06 & 68.23 & 40 & 11.78 & 57.11 \\
\hline 20 & 8.46 & 67.24 & 50 & 12.52 & 54.39 \\
\hline 25.3 & 8.73 & 66.54 & 60 & 16.36 & 37.72 \\
\hline $\mathbf{2 5 . 4}$ & 8.81 & 66.33 & 70 & 25.14 & 17.20 \\
\hline $\mathbf{2 5 . 5}$ & 8.82 & 66.31 & & & \\
\hline
\end{tabular}

Table 8

EXCITED STATE DIPOLE MOMENT AND POLARIZABILITY FOR DIFFERENT ANGLES $\varphi \in\left(0,79^{\circ}\right)$ FOR UV ABSORPTION BAND OF FLUORESCEIN

$$
\begin{gathered}
\alpha_{e}=78.0297-0.1507 \mu^{2} \\
0.0183 \mu_{e}^{2}-15.88 \mu_{e} \cos \varphi+124.9647=0 .
\end{gathered}
$$

In Eqs. (7) and (8) $\alpha_{e}$ is expressed in $\AA^{3}$, while $\mu_{e}$ is expressed in D. Equation (8) has real solutions for positive discriminator $\Delta$ :

$$
\Delta=252.1744 \cos ^{2} \varphi-9.1474 \text {. }
$$

The next condition is necessary to have real values for excited state dipole moment:

$$
\Delta \geq 0 \text { for } \varphi \leq 79.02^{\circ} .
$$

It results that the angle $\varphi$ between the molecular dipole moments in the electronic states of fluorescein must be smaller than $79^{\circ}$. Considering the value 7.94 D for the ground state dipole moment and $66.33 \AA^{3}$ for the ground state polarizability of fluorescein, one obtains the data from Table 8 for step by step variation of $\varphi$ with $10^{\circ}$.

For $\varphi \geq 25.5^{\circ}$ the molecular polarizability is smaller than the ground state polarizability of fluorescein. The electronic transition in UV absorption takes place at this angle.

\section{Conclusions}

Fluorescein molecule has been investigated by quantum mechanical and spectral measurements in order to determine its excited state dipole moment using only the information from electronic absorption spectrum. In UV domain of the fluorescein absorption spectrum, a $\pi \rightarrow \pi^{*}$ transition takes place, with increase of the molecular dipole moment.

Based on the quantum mechanical and spectral results, the dipole moment of fluorescein in the second excited electronic state $\pi^{*}$ is determined in this paper in the hypothesis that the molecular electric polarizability does not change its value in the absorption process. The angle between the dipole moments in the ground and excited states of fluorescein was also estimated.

\section{References}

1.VON BAEYER, A., Berichte der Deutschen Chemischen Gesellschaft zu Berlin, 4, 1871, p. 555.

2.MCQUEEN, P. D., SAGOO, S., YAO, H., JOCKUSCH, R. A., Angew. Chem., 122, 2010, p. 9379.

3.NADERI, F., FARAJTABAR, A., J. Mol. Liq., 221, 2016, p. 102.

4.BROUWER, A. M., Pure Appl. Chem., 83, 2011, p. 2213.

5.MURUBE, J., Ocul. Surf., 11, 2013, p. 212.

6.MURUBE, J., Ocul. Surf., 11, 2013, p. 144.

7.GARASZCZUK, I. K., ISKANDER, D. R., Cont. Lens Anterior Eye, 40, 2017, p. 208.

8.KASHANI, A. H., CHEN, C.-L., GAHM, J. K., ZHENG, F., RICHTER, G. M., ROSENFELD, P. J., SHI, Y., WANG, R. K., Prog. Retin. Eye Res., 60, 2017, p. 66.

9.REY-DIOS, R., COHEN-GADOL, A. A., Acta Neurochir., 155, 2013, p. 701.
10.KAKUCS, C., FLORIAN, I.-A., UNGUREANU, G., FLORIAN, I.-S., World Neurosurg., 105, 2017, p. 406.

11.ACERBI, F., CAVALLO, C., BROGGI, M., CORDELLA, R., ANGHILERI, E., EOLI, M., SCHIARITI, M., BROGGI, G., FERROLI, P., Neurosurg. Rev., 37, 2014, p. 547.

12.OH, D. K., JONES, R. N., MARSHALL, W., MAGIN, R. L., Skin Res. Technol., 7, 2001, p. 105.

13.PLATKOV, M., TIROSH, R., KAUFMAN, M., ZURGIL, N., DEUTSCH, M., J. Photochem. Photobiol. B-Biol., 140, 2014, p. 306.

14.NEGM, N. A., ABOU KANA, M. T. H., ABD-ELAAL, A. A., ELWAHY, A. H. M., J. Photochem. Photobiol. B-Biol., 162, 2016, p. 421.

15.HU, R.-R., YIN, Z.-Z., ZENG, Y.-B., ZHANG, J., LIU, H.-Q., SHAO, Y., REN, S.-B., LI, L., Biosens. Bioelectron., 78, 2016, p. 31.

16.VERES, P., KIRALI, G., NAGY, G., LAZAR, I., FABIÁN, I., KALMAR, J., J. Non-Cryst. Solids, 473, 2017, p. 17.

17.BAZYLEVICH, A., PATSENKER, L. D., GELLERMAN, G., Dyes Pigments, 139, 2017, p. 460.

18.FUENTES-PANIAGUA, E., SERRAMIA, M. J., SANCHEZ-NIEVES, J., ÁLVAREZ, S., MUNOZ-FERNANDEZ, M. A., GOMEZ, R., DE LA MATA, F. J., Eur. Polym. J., 71, 2015, p. 61.

19.BHATTACHARYA, S., AGARWAL, A. K., CHANDA, N., PANDEY, A., SEN, A. K. (Eds.), Environmental, Chemical and Medical Sensors, Springer Nature, Singapore, 2018.

20.WEBSTER, J. G., EREN, H. (Eds.), Measurement, Instrumentation, and Sensors Handbook. Electromagnetic, Optical, Radiation, Chemical, and Biomedical Measurement, CRC Press, Taylor \& Francis Group, Boca Raton, FL, 2014.

21.AL-AQMAR, D. M., ABDELKADER, H. I., ABOU KANA, M. T. H., Opt. Mater., 47, 2015, p. 573.

22.ABUTALIB, M. M., SHKIR, M., YAHIA, I. S., ALFAIFY, S., EL-NAGGAR, A. M., GANESH, V., Optik, 127, 2016, p. 6601.

23.FAROOQ, W. A., FATEHMULLA, A., YAKUPHANOGLU, F., YAHIA, I. S., ALI, S. M., ATIF, M., ASLAM, M., TAWFIK, W., Theor. Exp. Chem., 50, 2014, p. 121.

24.CHUA, L. H. C., ROBERTSON, A. P., YEE, W. K., SHUY, E. B., LO, E. Y. M., LIM, T. T., TAN, S. K., Ground Water, 45, 2007, p. 85.

25.GUAN, Y. J., WANG, J. C., HU, J., LI, Y. P., MA, W. G., HU, W. M., ZHU, S. J., Ind. Crops Prod., 45, 2013, p. 367.

26.NAKAMURA, A., TSUKIJI, S., Bioorganic Med. Chem. Lett., 27, 2017, p. 3127.

27.MARGULIES, D., MELMAN, G., SHANZER, A., Nat. Mater., 4, 2005, p 768.

28.CHOI, M. F., HAWKINS, P., Spectrosc. Lett., 27, 1994, p. 1049.

29.KLONIS, N., CLAYTON, A. H. A., VOSS JR., E. W., SAWYER, W. H., Photochem. Photobiol., 67, 1998, p. 500.

30.BISWAS, S., BHATTACHARYA, S. C., SEN, P. K., MOULIK, S. P., J. Photochem. Photobiol. A-Chem., 123, 1999, p. 121.

31.ACEMIOĐLU, B., ARIK, M., EFEOĐLU, H., ONGANER, Y., J. Mol. Struc.-Theochem, 548, 2001, p. 165.

32.MCHEDLOV-PETROSSYAN, N. O., IVANOV, V. V., Russ. J. Phys. Chem. A, 81, 2007, p. 112.

33.NADERI, F., FARAJTABAR, A., GHARIB, F., J. Mol. Liq., 190, 2014, p. 126.

34.MOROSANU, A. C., DIMITRIU, D. G., DOROHOI, D. O., J. Mol. Struct., 1180, 2019, p. 723. 
35.ABE, T., Bull. Chem. Soc. Japan, 38, 1965, p. 1314 and 39, 1966, p. 936.

36.DOROHOI, D. O., DIMITRIU, D. G., Studia Universitatis Babes Bolyai, Physica, Special Issue PIM 2001, 2001, p. 337.

37.TIGOIANU, R.I., DOROHOI, D.O., AIRINEI, A.,Rev. Chim. (Bucharest), 60, no. 1, 2009, p. 42.

38.TIGOIANU, R.I.,AIRINEI, A., DOROHOI, D.O., Rev. Chim. (Bucharest), 60, no. 5, 2010, p. 491.

39.YOUNG, D., Computational Chemistry: A Practical Guide for Applying Techniques to Real World Problems, John Wiley \& Sons, New York, 2001.

40.HEHRE, W., OHLINGER, S., Spartan'14 for Windows, Macintosh and Linux, Tutorial and User's Guide, Wavefunction Inc., Irvine, CA, 2014. 41.BAKHSHIEV, H. G., Spectroscopy of Intermolecular Interactions (in Russian), Nauka, Leningrad, 1972.

42.HURJUI, I., IVAN, L. M., DOROHOI, D. O., Spectrochim. Acta A, 102, 2013, p. 219.

43.*** http://www.stenutz.eu/chem/solv26.php (accessed on December 17, 2018).

44.GHEORGHIES, L. V., DIMITRIU, M., FILIP, E., DOROHOI, D. O., Rom. J. Phys., 55, 2010, p. 103.

45.GHEORGHIES, C., GHEORGHIES, L. V., DOROHOI, D. O., J. Mol. Struct., 887, 2008, p. 122.
46.BABUSCA, D., DOROHOI, D. O., Spectrochim. Acta A, 152, 2016, p. 149.

47.FLEMING, I., Frontier orbitals and organic chemical reactions, J ohn Wiley \& Sons, Chichester, 1976.

48.PARTHASARATHI, R., SUBRAMANIAN, V., ROY, D. R., CHATTARAJ, P. K., Bioorgan. Med. Chem., 12, 2004, p. 5533.

49. HITCHCOCK, S. A., PENNINGTON, L. D., J. Med. Chem., 49, 2006, p. 7559.

50.DOROHOI, D. O., DIMITRIU, D. G., DIMITRIU, M., CLOSCA, V., J. Mol. Struct., 1044, 2013, p. 79.

51.DOROHOI, D. O., Ukr. J. Phys., 63, 2018, p.701.

52.BABUSCA, D., MOROSANU, A. C., BENCHEA, A. C., DIMITRIU, D. G., DOROHOI, D. O., J. Mol. Liq., 269, 2018, p. 940.

53.MOROSANU, A. C., GRITCO-TODERASCU, A., CREANGA, D. E., DOROHOI, D. O., Spectrochim. Acta A, 189, 2018, p. 307.

54.BABUSCA, D., DIMITRIU, D. G., DOROHOI, D. O., Anal. Lett., 49, 2016, p. 2615.

55.BABUSCA, D., BENCHEA, A. C., DIMITRIU, D. G., DOROHOI, D. O., Anal. Lett., 50, 2017, p. 2740.

56.MOROSANU, A. C., BENCHEA, A. C., BABUSCA, D., DIMITRIU, D. G., DOROHOI, D. O., Anal. Lett., 50, 2017, p. 2725.

Manuscript received: 15.01 .2019 